\title{
PKM Creative Economy Assistance through Reusing Non-Organic Waste into Household Appliances
}

\author{
Temmy Wijaya ${ }^{1}$, Siti Astutik ${ }^{2}$, A' $^{\prime}$ isah $^{3}$, Lailatul Yakini ${ }^{4}$,
} Lisarotil Jamilah ${ }^{5}$, Nur Ayu Febriana ${ }^{6}$

Universitas Nurul Jadid, Probolinggo, Indonesia 1,2,3,4,5,6

\{temmy@gmail.com $\left.{ }^{1,2,3,4,5,6}\right\}$

\begin{tabular}{|c|c|}
\hline Submission: 19/1 & Received: 31/12/2021 \\
\hline $\begin{array}{l}\text { Keywords:; } \\
\text { creative } \\
\text { economy; non- } \\
\text { economic waste; } \\
\text { household } \\
\text { appliances }\end{array}$ & $\begin{array}{l}\text { Abstract. The problem of garbage was the classical problem that is } \\
\text { always faced by residents, especially in the Probolinggo City. Because } \\
\text { of the quantity and danger, plastic waste composed of chemicals was } \\
\text { difficult to decompose. Hence, it was dangerous for the environment. } \\
\text { Therefore, it was necessary to process waste to convert plastic into } \\
\text { crafts with aesthetic and selling value. This community service used } \\
\text { participation action research (PAR) through analysis surveys and } \\
\text { counselling and training. The processing of waste from plastic } \\
\text { packaging into handicrafts was being carried out to increase the } \\
\text { creativity and skills of the community, especially housewives, } \\
\text { unemployed youth and children who drop out of school. Besides that, } \\
\text { it can also minimize environmental pollution so that Probolinggo city } \\
\text { residents can care more about environmental cleanliness. Through } \\
\text { training and assistance in making creations for the use of waste } \\
\text { originating from plastic packaging, residents will have more } \\
\text { knowledge about business opportunities that can be created through } \\
\text { creativity and skills so that the economic level of residents becomes } \\
\text { higher. }\end{array}$ \\
\hline
\end{tabular}

Katakunci:

ekonomi kreatif, sampah non ekonomi, peralatan rumah tangga

\begin{abstract}
Abstrak. Masalah sampah merupakan masalah klasik yang selalu dihadapi oleh warga khususnya di Kota Probolinggo. Karena jumlah dan bahayanya, sampah plastik yang tersusun dari bahan kimia sulit terurai. Oleh karena itu, itu berbahaya bagi lingkungan. Oleh karena itu, perlu adanya pengolahan sampah untuk mengubah plastik menjadi kerajinan yang memiliki nilai estetika dan nilai jual. Penelitian ini menggunakan penelitian tindakan partisipasi (PAR) melalui survei analisis dan penyuluhan dan pelatihan. Pengolahan sampah dari kemasan plastik menjadi kerajinan tangan dilakukan untuk meningkatkan kreativitas dan keterampilan masyarakat khususnya ibu rumah tangga, pemuda pengangguran dan anak putus sekolah. Selain itu juga dapat meminimalisir pencemaran lingkungan sehingga warga kota Probolinggo dapat lebih peduli terhadap kebersihan lingkungan. Melalui pelatihan dan pendampingan dalam membuat kreasi pemanfaatan sampah yang berasal dari kemasan plastik, warga akan lebih memiliki pengetahuan tentang peluang usaha yang dapat diciptakan melalui kreativitas dan keterampilan sehingga tingkat ekonomi warga menjadi lebih tinggi.
\end{abstract}




\section{Introduction}

Nowadays, waste is one of the problems that are quite difficult to handle in Indonesia. It is because of the habits of the people as consumers who always produce waste, especially plastic, at every use of the product (Dewanti, \&Lubna Salsabila, 2020; Nurdiansah et al., 2020). along with the development of technology, the need for plastic increases. Plastic is an artificial inorganic material composed of chemicals that are difficult to decompose so that they are dangerous for the human environment (Mahyudin, et al., 2017; Mulasari et al., 20. Waste becomes an environmental problem because the quantity and level of danger interfere survival of living things (Hendrawa \& Haifan, 2020; Kahfi, 2017). A number of the difficulties encountered include seeing the condition of homemakers who do not have a side job, lack of awareness of the surrounding community indispose of waste in its place, which impacts environmental health, and lack of community participation in protecting the environment.

Based on this analysis, it can be concluded that the root of the problem in the location partners, namely the absence of information received by the community regarding the management method waste to be economically valuable and useful. Garbage accumulation in the urban village environment needs to be addressed with a systematic waste management program and add new income for the community. Given the high participation community in activities in their area, the empowerment program can become an alternative solution to problems in Karanganyar Village.

Therefore, the Community Partnership Program (PKM) offers training and mentoring inorganic waste into valuable goods economical, such as household furniture. It is an option because $70 \%$ of the population in around, especially PKK women, farmer groups who are always enthusiastic in filling free time for creativity to create environmentally friendly products. ProgramThis is offered by looking at the problems of partner villages, namely KelurahanKaranganyar, North Probolinggo District. Implementation of this program can be a strategy to increase public awareness to care about waste to obtain economic benefits from the garbage. An idea came up that this activity could be expanded, and there is reciprocity between consumers and producers while building creativity works owned to develop widely. Therefore, changing the trash plastic into reusable goods can help reduce 
environmental pollution. Creativity in using plastic waste into crafts hands is a good solution to turn plastic waste into useful items back (Sarmo et al., 2016; Aminudin \& Nurwati, 2019). Even it is a selling value and can be created into aesthetic value items (Shentika, 2016; Budiarti, et al., 2018). In community development activities held in Karanganyar, Probolinggo, the creativity given to local communities can be developed and benefit the community. This assistance aims to create a creative economy mentoring program through inorganic waste into quality household furniture.

\section{Method}

The method used is Participation Action Research (PAR) program for Utilizing Plastic Waste as Handicrafts in Karanganyar VillageProbolinggo North, Probolinggo City. Several techniques in implementation, namely 1. Survey analysis situation. 2. Implementation of extension and training consists of 3 activities, i.e. preparation, program implementation and evaluation of waste utilization. Training activities plastic into handicrafts with a selling value is done based on the community begins with the intended household waste sorting activity to avoid a decrease in the value of goods that can still be used and reduce the amount and composition of waste. Although this sorting activity is not directly reduced waste generation but can help the process waste reduction in further waste processing. Garbage sorting activities on a household scale are very easy to be done by housewives and housemaids who play a role in cleaning actors in every household.

\section{Results and Discussion}

Plastic waste is a serious environmental pollution problem, especially soil pollution. Plastic is an organic material that bacteria cannot decompose (Qomariah, \& Nursaid, 2020; Setiawan et al., 2020). And how it's better if the plastic waste can be used again by recycling and made into a new product. There have been many efforts to manage plastic waste recycling carried out by the government, such as by providing trash cans broken down into several categories of waste (wet and dry waste).

However, this strategy still has not yielded significant results in reducing the amount of plastic waste. In other words, the current management has 
not been fully effective. There are still many people who throw garbage by category of waste. Increased understanding of the community is necessary. It is done either by direct or indirect socialization. Such that expressed by several researchers who stated that in the implementation of waste management/management in a community, the first thing to do is to do waste reduction directly at the source of the waste(Hani \& Safitri, 2019; Budiman \& Saputra, 2019; Restanti et al., 2019). It takes an effective way so that in this activity, the collected plastic waste is separated based on the category of plastic-type so that the target cycle process that has been achieved in carrying out community empowerment activities in Karanganyar Village is very important satisfying. The community, especially mothers, was tremendous enthusiasm and a positive response from the village community Karanganyar-making it easier for event activities from start to finish in implementation. Especially in our flagship program, namely community empowerment through the creative use of used plastic cups to become quality household items, get a positive response from the village community.

In implementing this mentoring program, it is necessary to participate in this program: community empowerment actively. Therefore, initiated and formed a community consisting of the local community. As for developing the community, several stages are carried out, including:

First, Deliberation with the Community. The initial steps are to carry out consultations with local communities who greatly influence the society there, such as the head of the RT and the local lurah. This deliberation conveyed the aims and objectives of the program and asked for permission to realize the program. In addition, technical activities were also described in the form of socialization directly to the public through presentations and manuals on how to sortwaste, the economic benefits of waste, and program explanation.

Second, Cadre Training. The training is made in the form of socialization, discussion, and providing a simple module to guide administrators and the community manager. Cadres in Karanganyar Village are very active and enthusiastic in participating in activities. In addition to PKK cadres, in this cadre training, the Karangcadets and farmer groups also strengthened the initiation of 'Bakthis 'trash'. In this cadre training activity, there were 20 PKK cadres, five youth organizations, and two farmer groups, consisting of 6 farmers each. 
Third, training on the use of inorganic waste. In the implementation of activities. This community service is carried out with socialization and understanding of plastic waste use and then training in making handicrafts that come from plastic waste. Plastic waste recycling management/management strategy effectively involves the community (waste-producing sources) directly and related informal recycling institutions, accompanied by-elections efficient and ergonomic technology and facilities to increase empowerment public. With plastic waste craft training, you can improve your income households with community empowerment and reduce the number of plastic waste.

Fourth is the implementation of the program by the community (Follow up and follow up)control). At this stage, the waste bank program will be followed up related to the development of the coaches. Through this program, the formed community has been able to carry out a work program that has been designed together. It is hoped that after a few months or a few years, the Karanganyar village can create a community that has the ability and skills to utilize the results of the waste bank into goods of economic value.

Community Empowerment Activities are held in the Hall Building. The event begins at 08.00. It starts with a joint exercise between mothers and members of the mother's group- PKK women and the local community in Probolinggo, namely stick gymnastics, aerobics, and Zumba gymnastics. The community is enthusiastic about participating in joint gymnastics ActivitiesCommunity Empowerment can go according to plan and smoothly. Excited ladies helped the event from start to finish. Materials and tools are used to make creativity in making household items, namely plastic cups that have been shaped as needed, colourful parcel rope, scissors/cutter, and pliers. These materials are assembled and shaped into household items such as drinking glasses, tissue holders, candy containers, fruit containers, and other crafts. Then the event ended with a group photo. Some natural driving factors in carrying out activities in Karanganyar Village include several driving and obstacles in the implementation of activities, including community enthusiasm in activities, skills and patience, and the amount of plastic waste.

In this assistance, the facilitator works with several multi-stakeholders such as PKK, Farmer Groups, Youth Organizations, and the surrounding community. Lotsparties involved or play a role in implementing our program, 
especially theOur flagship, are community empowerment through the creative use of glass used plastic into quality household items. Some Followup or follow-ups we do is that we regularly attend meetings with PKK women. Socialization by gathering PKK women, CadrePosyandu, Muslim women, farmer groups, and youth groups to carry out activities.

The contribution of this assistance is like the community, especially through the use of plastic glass waste as a work that has a selling value more and also help preserve the environment because this product is environmentally friendly. In addition, it is one of the program activities carried out by the community, especially mothers. It became the group's flagship program which is realized and well received by society.

Implementation of community empowerment in Karanganyar hamlet through management waste can be seen from 3 aspects, namely, education, health, and economy. Factors that support community empowerment through waste management are skills, patience, and the spirit of the women in Karanganyar Village. Citizens' awareness of environmental cleanliness and motivation to get skills and additional family income. The inhibiting factors the process of community empowerment through waste management, namely people interested in waste management only a few. The waste management hopes that the waste produced by the community and managed properly will not become a problem again. In this case, the community is placed as the perpetrator or facilitator in waste management. The public is educated in selecting waste that they generate themselves and empowers the community with savings waste and recycling of waste.

The results of this study strengthen several previous studies, such as Dewanti \&Salsabila (2020), which utilizes convection waste to increase income for poor households (RTM). Which one uses patchwork can add skills of villagers in utilizing convection waste into products that are worth selling. In addition, several previous studies stated that education about the danger of spiling up convection waste into cloth waste provides additional knowledge to students villagers to maintain environmental health by recycling waste convection (Amir, 2019; Devanti, 2017). Likewise, the use of inorganic waste positively impacts economic and social conditions (Ponisri, \&Soekamto, 2020). Through empowering and optimizing the existing 
community in society, it can bring about change so that it can provide opportunitiesnew businesses and impact the people's economy.

\section{Conclusion}

After conducting field observations and proceeding with making a plan excellent work program. Public awareness of environmental cleanliness and community motivation to acquire skills and additional income family. The mentoring activities that have been held have received a very positive response from the people of Karanganyar Village. It can be seen from the program activitiesexcellence that has been made to be carried out properly. Through the use ofthe plastic cup waste as a work that has more selling value and helps to preserve the environment because this product is environmentally friendly, such as a place to drink, place tissues, fruit containers, candy places and so on.

\section{References}

Aminudin, A., \& Nurwati, N. (2019). Utilizing Plastic Waste Into CraftsHands to Increase the Creativity of Residents Around Stie Ahmad Dahlan Jakarta. Journal of Abdimas BSI: Journal of Community Service, 2 (1).

Amir, M. (2019). Utilization of Inorganic Waste by Housewives' Group inPangkep Regency. DEDICATION , 20 (1).

Budiman, A., \& Saputra, AR (2019). Development of a home biogas model forreduce livestock waste (waste) in Kananga Village, Bolo District, Regencybima. Journal of State Administration, 16 (2).

Budiarti, W., Susilowati, S., \& Farida, I. (2018). Efforts to Utilize Plastic WasteDasawisama Gladiolus 161 Women's Group at Magersari Permai Housing,Sidoarjo Regency. Journal of Professional Communication , 2 (2).

Dewanti, M., EP, EPP, \& Lubna Salsabila, L. (2020). Analysis of the effectiveness of the waste bankas an alternative to waste management in achieving a smart city in the districtkulon progo. Journal of Public Administration Science , 5 (1), 21-29. 
Devanti, YM (2017). Utilization of convection waste to increase incomepoor households (RTM). Science and Technology Community Service Journal , 3 (1).

Hani, M., \& Safitri, DP (2019). Waste Bank Capacity Development for ReducingGarbage in Tanjungpinang City. STEERING: Journal of Government Science , 4 (1), 123-143.

Hendrawan, I., \& Haifan, M. (2020). Waste management into place-based energylocal waste management (toss) in the city of south tangerang. Abdi Laksana , 1 (1).

Kahfi, A. (2017). Overview of Waste Management. Jurisprudentie: Department of Science Law Faculty of Sharia and Law , 4 (1), 12-25.

Mahyudin, Rizqi Puteri. (2017) "A study of waste management problems and impactsenvironment in TPA (Final Processing Site)." Jukung (Journal of Environmental Engineering)3.1

Mulasari, SA, Husodo, AH, \& Muhadjir, N. (2016). Analysis of the situation of the waste problemYogyakarta city and its management policies. PACKAGE: Journal of HealthSociety, 11 (2), 259-269.

Nurdiansah, T., Purnomo, EP, \& Kasiwi, A. (2020). power plant implementationwaste power (PLTS) as a solution to urban waste problems; case studyin the city of Surabaya. envirotek: Scientific Journal of Environmental Engineering , 12 (1), 87-92.

Ponisri, P., \& Soekamto, MH (2020). Utilization of Inorganic Waste for ArrangementParks in Malawele Village. Abdimas: Papua Journal of Community Service , 2 (1),23-29. https://doi.org/10.33506/pjcs.v2i1.810

Qomariah, N., \& Nursaid, N. (2020). Socialization of Reduction of Plastic Materials in the Community.Journal of Community Service Manage , 1 (1), 43-55.

Restanti, E., Thohari, I., \& Rachmaniyah, R. (2019). Effectiveness of Reducing Organic Wastein Biopori (Study in Sekargadung Village, Dukun District, Gresik Regency)2018). Journal of Health Research" SUARA FORIKES"(Journal of HealthResearch" Forikes Voice") , 10 (3), 168-172. 
Sarmo, S., Andilolo, IR, Mulyadi, M., \& Darwini, S. (2019). Waste managementin the southern hamlet of the village of giri Sasak perendekan. Unified Proceedings , 1 (1), 93-96.

Setiawan, R., Dharma, US, \& Andriyansyah, N. (2020). Making plastic oil withstratified distillation method. ARMATUR (Mechanical \& Manufacturing Engineering Article) , 1 (1),35-40.

Shentika, PA (2016). Waste bank management in Probolinggo City. Journal of Economics andDevelopment Studies, 8 (1), 92-100 